\title{
Thermographic evaluation of healing process on patients after surgery of cataract with the use of facoemulsyphication
}

\author{
by Kalisz O. ${ }^{1}$, Gerkowicz M. ${ }^{1}$, Wolski T. ${ }^{4}$, Goździuk K. ${ }^{3}$, Baranowski P. ${ }^{2}$, Mazurek W. ${ }^{2}$, Rozegnał- \\ Madej A.
}

\author{
${ }^{1}$ Clinic of Ophthalmology of Medical University in Lublin, Poland \\ ${ }^{2}$ Institute of Agrophysics, Polish Academy of Sciences, Lublin, Poland \\ ${ }^{3}$ Department and Clinic of Surgery of Chest of Medical University in Lublin, Poland \\ ${ }^{4}$ Department and Unit of Pharmacognozy of Medical University in Lublin, Poland
}

\begin{abstract}
Presented investigations are a part of an interdisciplinary research programme which covers various medical disciplines. It aims at evaluation of application of thermography for evaluation of healing process on patients after surgery of cataract. It was revealed that the mean temperature in the operating eyes was much higher in the first and fifth day after operation when the operation lasted longer or in case of longer use of ultrasounds. The results confirm that on the base of thermographic data an indicator of healing process can be created.
\end{abstract}

\section{Introduction}

According to the World Health Organization the main cause of vision degradation and blindness all over the world is cataract. Every year alongside with population aging, the percentage of people who are loosing their ability of sight is growing. About 17 million people on the world suffer against reversible blindness and the number will grow to 40 million until year 2020 [1].

The most often met form of cataract is senile cataract. Considerably more rarely cataract takes a stand about metabolic, traumatic or congenital basis. We say depending on degree of the lens opacity about incipient, immature or mature cataract. In this last case the lens opacity is complete. Hypermature cataract or morgagnian type is diagnosed in very not numerous cases.

There is separate question about secondary cataract, called also complicated cataract, which develops owing to existence of another, primary eye disease. Most frequent reason is chronic anterior uveitis [2]. Reasons mentioned among others are glaucoma, high myopia, inherited retinal dystrophy, pseudoexfoliation syndrome and retinopathy emerging in course of long-term diabetes or hypertension.

Operative procedure is sole forceful method of procedure in case of lens opacity that handicaps vision. There are two main cataract surgery types - intracapsular and extracapsular extraction.

The primary method of cloudy lens removal was her all-out with capsule mining by intracapsular extraction. This method was almost completely substitute with an extracapsular technique, along with more advanced operative microscopes, aspiration systems, and better intraocular implants appearance. The last one relies on lens nucleus and cortex removal through opening of an anterior face of the capsule that contains the lens inside the eye, with posterior capsule of the lens saved. Final stage of the procedure is properly fitted artificial intraocular lens implantation [4,5]. Those are rather foldable intraocular lens implants (IOL) placed into the posterior chamber within remaining posterior lens capsule, than unfoldable IOL or placed in anterior chamber implants.

Phacoemulsification is a modification of an extracapsular cataract extraction, which differs from the conventional technique with smaller corneal incision and manner of core removal. The surgeon involves the use of an ultrasonic handpiece with a titanium or steel needle. The tip of the needle vibrates at ultrasonic frequency to sculpt and emulsify the nucleus while the pump aspirates particles through the tip. It is thought generally, that employment of this method not only decreases amount of complications related with surgical wound, but also speeds up healing process and visual rehabilitation (tab.1). This thesis was one of many, that following research had to verify for task.

Static infrared thermal imaging, popularly known as static thermography, has many advantages due to which can be useful in modern medicine and eye diseases diagnostics. This functional image measures metabolic activity in the tissue, blood flow changes and what fallows behind temperature changes with accuracy for $0,025^{\circ} \mathrm{C}$ and thus can detect local abnormalities very early. This imaging modality is noninvasive, nonionizing and harmless as there is no direct contact of the diagnostic tool to an object under test.

The data acquisition is simple and the equipment is transportable and well adapted to mass screening applications [3]. Moreover, the depth of penetration of infrared waves is approximated for length of eyeball, what presents additional feature behind utilization of thermography in ophthalmological research saying. 
Table 1. Complications of cataract surgery with intraocular lens implant (IOL)

\begin{tabular}{|l|l|}
\hline Early complications & Late complications \\
\hline Endophthalmitis & \\
Wound dehiscence / iridocele & Bullous keratopathy \\
Hyphema & Malposition / dislocation of IOL \\
Hypopyon & Clinical cystic macular edema \\
Iris injury & Retinal detachment \\
Zonulodialysis/ posterior capsular tear & Uveitis \\
Vitreous outflow & Intraocular pressure increase \\
Intravitreous hemorrhage & Posterior capsule opacification \\
Extrauveal hemorrhage & \\
Corneal edema & \\
\hline
\end{tabular}

\section{Purpose of the study}

The major challenge for the research was the evaluation of healing process after cataract surgery with phacoemulsification using an eye thermography. It was to explore the potential dependences among ultrasound frequency or total time of ultrasound use, among fluid dynamics or duration of whole operative procedure but degree of inflammatory reaction in eyeball. Also termography results depending on kind of anesthesia (retrobulbar block or topical anesthesia with lidocaine eyedrops), type of cataract and finally medications applied after surgery were investigated.

\section{Methods}

There were 20 patients for the research included, which were qualified for cataract surgery using a phacoemulsification. 7 persons with clear lens presented the check group. Data were assembled 1 day before cataract extraction, 1 day after surgery and 5 days after procedure. It executed measurements of intraocular tension, visual acuity, ocular fundus and evaluation of the anterior eye segment including inflammatory reaction and corneal edema connected with performed procedure. Each patient had executed temperature measurements of both of eyes in each time research twice. For results comparison it was taken into account average values of temperatures from surface of operated eyes. Research were carried in standardized conditions of temperatures and humidity of enclose. Tests were done using the VIGOcam v50 by VIGO System S.A. thermal imaging set. This system is equipped with a CCD camera. Visible range images were useful to localize particular parts of the eye on thermographic images. A firmware software THERM was used to analyze obtained thermograms. For each patients both right and left eyes were studied. Using measurement in six points on each eye average temperatures were calculated. Thermographical results were analyzed with reference to duration of operation, total time of ultrasound use, fluid dynamics, kind of anesthesia and medications applied after cataract surgery.

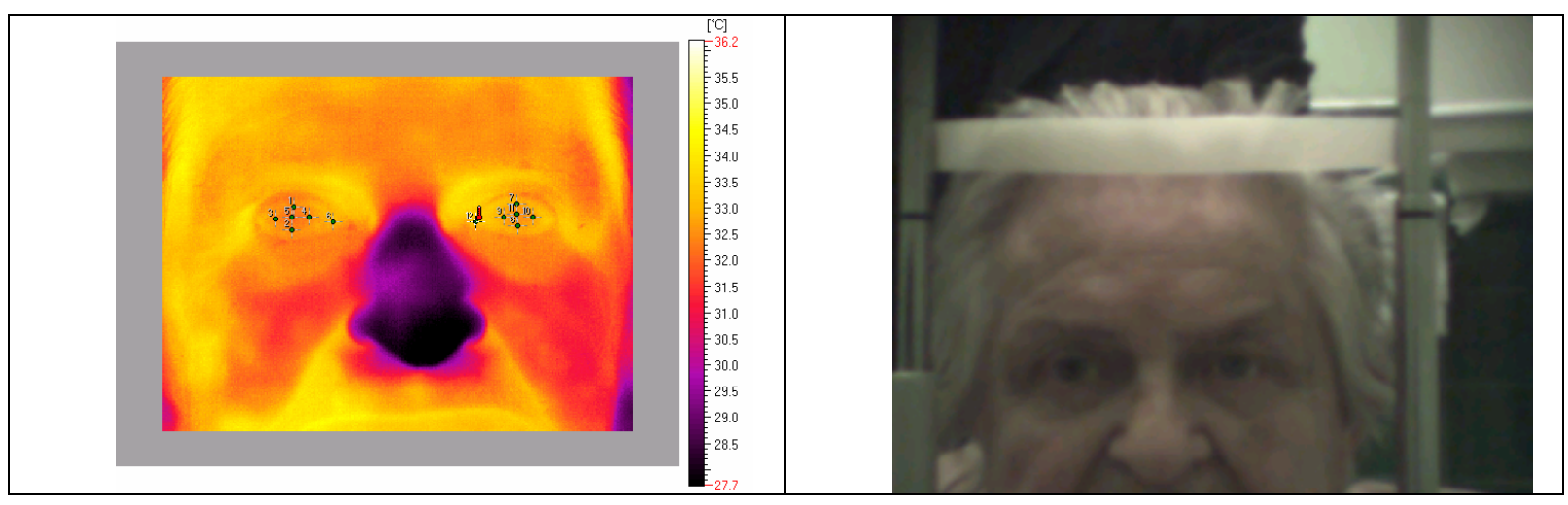

Fig. 1. Example of a thermogram with studied points and visible range image of a patient

19 patients finished the research -9 men and 10 women. Average age of researched patients was 72.63 years. left eye)

Comparison of thermal imaging results depending on total time of ultrasound use. (RE is right eye, LE is

Group 1 - total time of ultrasound use equal or less than 33 seconds (10 patients).

Patients with numbers:

7(RE),8(RE),9(LE),10(RE),11(LE),12(RE),13(LE),14(RE),16(LE),17(LE) 
Group 2 - total time of ultrasound use more than 33 seconds (9 patients).

Patients with numbers:

1(RE),2(RE),3(RE),4(LE),5(LE),6(LE),15(LE),18(RE),19(RE)

Comparison of thermal imaging results depending on duration of operation.

Group 3-duration of operation equal or less than 13 minutes (8 patients).

Patients with numbers:

5(LE),8(RE),9(LE),10(RE),11(LE),13(LE),14(RE),17(LE)

Group 4 - duration of operation more than 13 minutes (11 patients).

Patients with numbers:

1(RE),2(RE),3(RE),4(LE),6(LE),7(RE),12(RE),15(LE),16(LE),18(RE), 19(RE)

\section{Results}

Data concerning temperature measurement results are presented in tables 2,3,4 and 5 below.

Table 2. Data of thermal imaging results for eyes after cataract surgery-group 1.

\begin{tabular}{|l|c|c|c|c|c|c|c|c|c|c|c|c|}
\hline Patient number & 7 & 8 & 9 & 10 & 11 & 12 & 13 & 14 & 16 & 17 & $\begin{array}{l}\text { Average } \\
\text { difference of } \\
\text { temperature }\end{array}$ & $\begin{array}{l}\text { Standard } \\
\text { deviation }\end{array}$ \\
\hline $\begin{array}{l}\text { Difference of temperature between } \\
\text { measurement in first day after } \\
\text { procedure and before operation. }\end{array}$ & 0,56 & 0,33 & 0,45 & 0,32 & 0,34 & 0,51 & 0,27 & 0,23 & 0,55 & 0,41 & 0,40 & 0,12 \\
\hline $\begin{array}{l}\text { Difference of temperature between } \\
\text { measurement in fifth day after } \\
\text { procedure and before operation. }\end{array}$ & 0,70 & 0,06 & 0,08 & 0,01 & 0,06 & 0,52 & 0,07 & 0,19 & 0,42 & 0,16 & 0,14 & 0,30 \\
\hline
\end{tabular}

As it was revealed the average difference of temperatures between first day after procedure and before operation was $0.4^{\circ} \mathrm{C}+/-0.12^{\circ} \mathrm{C}$ in group 1 , where total time of ultrasound use was equal or less than 33 seconds. This difference in group 2, where total time of ultrasound use was more than 33 seconds, was almost twice greatest and it totaled $0.77^{\circ} \mathrm{C}+/-0.17^{\circ} \mathrm{C}$. The difference between measurements in fifth day after procedure and before surgery was properly $0.14^{\circ} \mathrm{C}+/-0.3^{\circ} \mathrm{C}$ in group 1 and $0.94^{\circ} \mathrm{C}+/-0.23^{\circ} \mathrm{C}$ in group 2 .

Table 3. Data of thermal imaging results for eyes after cataract surgery-group 2

\begin{tabular}{|l|c|c|c|c|c|c|c|c|c|c|c|}
\hline Patient number & 1 & 2 & 3 & 4 & 5 & 6 & 15 & 18 & 19 & $\begin{array}{l}\text { Average } \\
\text { difference of } \\
\text { temperature }\end{array}$ & $\begin{array}{l}\text { Standard } \\
\text { deviation }\end{array}$ \\
\hline $\begin{array}{l}\text { Difference of temperature between } \\
\text { measurement in first day after procedure } \\
\text { and before operation }\end{array}$ & 0,60 & 0,87 & 0,87 & 0,92 & 0,50 & 0,72 & 0,74 & 0,65 & 1,03 & 0,77 \\
\hline $\begin{array}{l}\text { Difference of temperature between } \\
\text { measurement in fifth day after procedure } \\
\text { and before operation. }\end{array}$ & 0,84 & 1,00 & 0,92 & 1,08 & 0,48 & 0,88 & 1,15 & 0,86 & 1,28 & 0,17 \\
\hline
\end{tabular}

Table 4. Data of thermal imaging results for eyes after cataract surgery-group 3

\begin{tabular}{|l|c|c|c|c|c|c|c|c|c|c|}
\hline Patient number & 5 & 8 & 9 & 10 & 11 & 13 & 14 & 17 & $\begin{array}{l}\text { Average } \\
\text { difference of } \\
\text { temperature }\end{array}$ & $\begin{array}{l}\text { Standard } \\
\text { deviation }\end{array}$ \\
\hline $\begin{array}{l}\text { Difference of temperature between } \\
\text { measurement in first day after procedure and } \\
\text { before operation }\end{array}$ & 0,50 & 0,33 & 0,45 & 0,32 & 0,34 & 0,27 & 0,23 & 0,41 & 0,36 \\
\hline $\begin{array}{l}\text { Difference of temperature between } \\
\text { measurement in fifth day after procedure and } \\
\text { before operation. }\end{array}$ & 0,48 & 0,06 & 0,08 & 0,01 & 0,06 & 0,07 & 0,19 & 0,16 & 0,03 & 0,09 \\
\hline
\end{tabular}


Table 5. Data of thermal imaging results for eyes after cataract surgery-group 4

\begin{tabular}{|l|c|c|c|c|c|c|c|c|c|c|c|c|c|}
\hline Patient number & 1 & 2 & 3 & 4 & 6 & 7 & 12 & 15 & 16 & 18 & 19 & $\begin{array}{l}\text { Average } \\
\text { difference of } \\
\text { temperature }\end{array}$ & $\begin{array}{l}\text { Standard } \\
\text { deviation }\end{array}$ \\
\hline $\begin{array}{l}\text { Difference of temperature } \\
\text { between measurement in first } \\
\text { day after procedure and } \\
\text { before operation }\end{array}$ & 0,60 & 0,87 & 0,87 & 0,92 & 0,72 & 0,56 & 0,51 & 0,74 & 0,55 & 0,65 & 1,03 & 0,73 & 0,17 \\
\hline $\begin{array}{l}\text { Difference of temperature } \\
\text { between measurement in fifth } \\
\text { day after procedure and } \\
\text { before operation. }\end{array}$ & 0,84 & 1,00 & 0,92 & 1,08 & 0,88 & 0,70 & 0,52 & 1,15 & 0,42 & 0,86 & 1,28 & 0,88 & 0,26 \\
\hline
\end{tabular}

Table 6. Data of thermal imaging results for eyes without cataract surgery - group 1

\begin{tabular}{|l|c|c|c|c|c|c|c|c|c|c|c|c|}
\hline Patient number & 7 & 8 & 9 & 10 & 11 & 12 & 13 & 14 & 16 & 17 & $\begin{array}{l}\text { Average } \\
\text { difference of } \\
\text { temperature }\end{array}$ & $\begin{array}{l}\text { Standard } \\
\text { deviation }\end{array}$ \\
\hline $\begin{array}{l}\text { Difference of temperature between } \\
\text { measurement in first day after } \\
\text { procedure and before operation }\end{array}$ & 0,24 & 0,19 & 0,15 & 0,04 & 0,12 & 0,27 & 0,23 & 0,09 & 0,26 & 0,80 & 0,03 & 0,33 \\
\hline $\begin{array}{l}\text { Difference of temperature between } \\
\text { measurement in fifth day after } \\
\text { procedure and before operation. }\end{array}$ & 0,17 & 0,29 & 0,27 & 0,07 & 0,09 & 0,07 & 0,02 & 0,17 & 0,18 & 0,54 & 0,10 & 0,23 \\
\hline
\end{tabular}

Table 7. Data of thermal imaging results for eyes without cataract surgery-group 2

\begin{tabular}{|l|c|c|c|c|c|c|c|c|c|c|c|}
\hline Patient number & 1 & 2 & 3 & 4 & 5 & 6 & 15 & 18 & 19 & $\begin{array}{l}\text { Average } \\
\text { difference of } \\
\text { temperature }\end{array}$ & $\begin{array}{l}\text { Standard } \\
\text { deviation }\end{array}$ \\
\hline $\begin{array}{l}\text { Difference of temperature between } \\
\text { measurement in first day after procedure and } \\
\text { before operation }\end{array}$ & 0,08 & 0,22 & 0,15 & 0,27 & 0,30 & 0,42 & 0,47 & 0,11 & 0,29 & 0,09 & 0,28 \\
\hline $\begin{array}{l}\text { Difference of temperature between } \\
\text { measurement in fifth day after procedure and } \\
\text { before operation. }\end{array}$ & 0,10 & 0,16 & 0,01 & 0,31 & 0,09 & 0,05 & 0,45 & 0,11 & 0,12 & 0,01 & 0,22 \\
\hline
\end{tabular}

Table 8. Data of thermal imaging results for eyes without cataract surgery-group 3

\begin{tabular}{|l|c|c|c|c|c|c|c|c|c|c|}
\hline Patient number & 5 & 8 & 9 & 10 & 11 & 13 & 14 & 17 & $\begin{array}{l}\text { Average } \\
\text { difference of } \\
\text { temperature }\end{array}$ & $\begin{array}{c}\text { Standard } \\
\text { deviation }\end{array}$ \\
\hline $\begin{array}{l}\text { Difference of temperature between measurement } \\
\text { in first day after procedure and before operation }\end{array}$ & 0,30 & 0,19 & 0,15 & 0,04 & 0,12 & 0,23 & 0,09 & 0,80 & 0,03 & 0,35 \\
\hline $\begin{array}{l}\text { Difference of temperature between measurement } \\
\text { in fifth day after procedure and before operation. }\end{array}$ & 0,09 & 0,29 & 0,27 & 0,07 & 0,09 & 0,02 & 0,17 & 0,54 & 0,15 & 0,22 \\
\hline
\end{tabular}


Table 9. Data of thermal imaging results for eyes without cataract surgery - group 4

\begin{tabular}{|l|c|c|c|c|c|c|c|c|c|c|c|c|c|}
\hline Patient number & 1 & 2 & 3 & 4 & 6 & 7 & 12 & 15 & 16 & 18 & $\begin{array}{l}19 \\
\text { Average } \\
\text { difference of } \\
\text { temperature }\end{array}$ & $\begin{array}{l}\text { Standard } \\
\text { deviation }\end{array}$ \\
\hline $\begin{array}{l}\text { Difference of temperature } \\
\text { between measurement in first day } \\
\text { after procedure and before } \\
\text { operation }\end{array}$ & 0,08 & 0,22 & 0,15 & 0,27 & 0,42 & 0,24 & 0,27 & 0,47 & 0,26 & 0,11 & 0,29 & 0,07 \\
\hline $\begin{array}{l}\text { Difference of temperature } \\
\text { between measurement in fifth day } \\
\text { after procedure and before } \\
\text { operation. }\end{array}$ & 0,10 & 0,16 & 0,01 & 0,31 & 0,05 & 0,17 & 0,07 & 0,45 & 0,18 & 0,11 & 0,12 & 0,28 \\
\hline
\end{tabular}

In group 3 (duration of operation equal or less than 13 minutes) the difference of temperatures between an operated eye in first day after procedure and before operation was $0.36^{\circ} \mathrm{C}+/-0.09{ }^{\circ} \mathrm{C}$, however in group 4 (duration of operation more than 13 minutes) it was $0.73^{\circ} \mathrm{C}+/-0.17^{\circ} \mathrm{C}$. Differences of temperature between measurements in fifth day after surgery and measurements before procedure were $0.03^{\circ} \mathrm{C}+/-0.21^{\circ} \mathrm{C}$ in group 3 and $0.88^{\circ} \mathrm{C}+/-0.26^{\circ} \mathrm{C}$ in group 4 .

These differences were not notified for the other eye of the patient, without cataract surgery. These data are presented in tables $6,7,8$ and 9 .

\section{Conclusions}

As it was revealed the mean temperature in the operating eyes was much higher in the first and fifth day after operation when the operation lasts longer or in case of longer use of ultrasounds. These data could be the indicator of healing process and be a result of intensity of inflammatory reaction.

Longer time of operation is usually connected with higher flow of infusion fluids which could also affects the healing process.

Statistically significant differences were not observed in non-operating eyes. There were no differences depending on anaesthetic methods.

As was indicated earlier the thermographic method can be used in postsurgery evaluation of patients state after the operation of cataract.

This method is useful for evaluation of the impact of operation course on the process of healing. As can be deduced from the performed analyses the time of surgery and the short period of ultrasounds action as well as application of small flows of perfusion fluids during the operation enable to create optimal surgery conditions which determine proper process of healing after the operation and postsurgery clinical effectiveness.

\section{REFERENCES}

[1] Basic and Clinical Science Course. Część 11. Soczewka i Zaćma. Pod red. Józefa Kałużnego. Wyd. 1, Wrocław: Elsevier Urban \& Partner, (2007). ISBN 978-83-89581-64-8.

[2] N.A. Diakides, J.D. Bronzino. Medical Infrared Imaging, CRC Press, Taylor\&Francis Group, LLC (2008).

[3] G. Eisner, P. Schneider, T.C. Telger. Eye surgery: An introduction to operative technique. 2nd ed. New York, Springer-Verlag, (1990).

[4] I.H. Fine. The chip and flip phacoemulsification technique. J. Cataract Refract Surg. (1991) 17, 366-71.

[5] J.J. Kański. Okulistyka Kliniczna. Wyd. 2. Wrocław: Górnicki Wydawnictwo Medyczne, (2005). ISBN 8389009-30-7. 
http://dx.doi.org/10.21611/qirt.2008.03_04_17 